\title{
Identifying Storm Hotspots and the Most Unsettled Areas in Barcelona by Analysing Significant Rainfall Episodes from 2013 to 2018
}

\author{
Laura Esbrí $^{1, *(\mathbb{D})}$, Tomeu Rigo ${ }^{2}\left(\mathbb{D}\right.$, María Carmen Llasat ${ }^{1}(\mathbb{D})$ and Blanca Aznar $^{3}$ \\ 1 GAMA Team, Department of Applied Physics, University of Barcelona, 08028 Barcelona, Spain; \\ carmell@meteo.ub.edu \\ 2 Meteorological Service of Catalonia (Servei Meteorològic de Catalunya-SMC), 08029 Barcelona, Spain; \\ tomeu.rigo@gencat.cat \\ 3 Barcelona Cicle de l'Aigua S.A. (BCASA), 08038 Barcelona, Spain; baznars@bcn.cat \\ * Correspondence: lesbri@meteo.ub.edu
}

Citation: Esbrí, L.; Rigo, T.; Llasat, M.C.; Aznar, B. Identifying Storm Hotspots and the Most Unsettled Areas in Barcelona by Analysing Significant Rainfall Episodes from 2013 to 2018. Water 2021, 13, 1730 . https://doi.org/10.3390/w13131730

Academic Editor: Renato Morbidelli

Received: 20 May 2021

Accepted: 21 June 2021

Published: 22 June 2021

Publisher's Note: MDPI stays neutral with regard to jurisdictional claims in published maps and institutional affiliations.

Copyright: () 2021 by the authors. Licensee MDPI, Basel, Switzerland. This article is an open access article distributed under the terms and conditions of the Creative Commons Attribution (CC BY) license (https:// creativecommons.org/licenses/by/ $4.0 /)$.

\begin{abstract}
Urban floods repeatedly threaten Barcelona, damaging the city infrastructure and endangering the safety of the population. The urban planning of the city, the socioeconomic distribution, its topography, and the characteristics of precipitation systems translate into these flood events having a heterogeneous effect across the city. It means that the coping capacity has a strong dependence on local factors that must be considered when management plans are developed by the municipality. This work aims to contribute to the better knowledge of precipitation structures associated with heavy rainfall events and floods in Barcelona based on radar data and an urban rain gauge network. Radar data have been provided by the Meteorological Service of Catalonia (SMC), while precipitation data, impact data, and early warnings, have been provided by Barcelona Cicle de l'Aigua S.A. (BCASA), for the period 2013-2018. A new radar-based methodology has been developed to identify convective rainfall structures from radar reflectivity volumes (CAPPI and TOP products) to make the analysis easier. The high computing speed of the procedure allows efficient analysis of a large set of convective cells without scarifying temporal resolution of radar data. Both rainfall fields (radar and rain gauge, respectively) have been compared. Then through the identified rainfall convective structures, thunderstorm hotspots have been identified. Considering an alert indicator from BCASA and the reported incidents, episodes with the highest impact have been analysed in depth. Results show 207 significant rainfall episodes in the ROI for the six years, which are mainly concentrated between September and November. The fact that significant episodes are usually produced by highly convective rain corroborates the advantage of using radar images as a tool to detect any maxima even when no rain gauge is there. In 64 of the episodes, the level of pre-alert was achieved with a maximum frequency between August and September. The proposed algorithm shows more than 8000 centroids of convective cells from 189 cases. Whilst maximum surface reflectivity over $45 \mathrm{dBZ}$ is more prone to occur near the coastline, the centroids of storm cells tend to concentrate more inland. The final objective is to improve the actions taken by the organisation responsible for managing urban floods, which have seen Barcelona recognised as a model city for flood resilience by the United Nations.
\end{abstract}

Keywords: flash floods; urban floods; storms; hazard management; urban hydrology; convection; convective cells; thunderstorms; radar; flood prevention; Mediterranean

\section{Introduction}

Hydrometeorological hazards especially affect the Mediterranean basin, where heavy rainfalls play an important role and usually produce flash floods, surface floods and urban floods. Most of the floods are concentrated inside a geographical belt that runs from the western Mediterranean to the Black Sea [1]. In Catalonia (NE of the Iberian Peninsula, and NW of the Mediterranean Basin), floods are the most damaging natural hazard [2], 
with a mean rate of over eight flood episodes per year [3]. During the 1981-2015 period, more than 250 cases were identified, most of them near the coastline [3-5]. As a result, the Spanish Insurance Compensation Consortium (in Spanish, Consorcio de Compensación de Seguros-CCS) paid out over 450 million euros between 1996 and 2015. Furthermore, other private insurance expenses must be added. Highly convective and very localised precipitation is responsible for $70 \%$ of the flood episodes along the Catalan coast $[6,7]$, affecting the most densely populated Catalan counties in one out of three cases.

According to the flood classification in Barrera et al. [8], Llasat et al. [9] showed that $36 \%$ of the floods (including flash floods, riverine floods, surface water floods, and urban floods) recorded in Catalonia between 1982 and 2010 were ordinary (no damages or minor ones), 53\% were extraordinary (moderate damages) and $11 \%$ were catastrophic (major damages). There is no significant trend related to catastrophic floods in Catalonia, but the number of extraordinary floods has increased in recent years [3,8-10]. Explaining this trend requires considering not only hydrometeorological hazards but also vulnerability, exposure and coping capacity [11-14]. Still, recent studies point towards an increase in flood risk but more to an increase in the associated socioeconomic impact [15]. Strong social commitment and sustainable efforts are needed to increase flood prevention and resilience [16]. This can only be achieved through better empowerment and co-responsibility at every level, based on improved knowledge of prevention and forecasting [17].

A study on regions in the United States by Naylor and Sexton [18] concluded that the urbanisation of metropolitan areas may have changed the location of convective storm cells and precipitation fields. In the Mediterranean region, there is a significant interaction between urbanisation and convective precipitation, as most floods are caused by very heavy and local precipitation in urbanised areas [7]. The topographic characteristics of the Mediterranean region, in combination with its geographical location and the presence of a warm sea, mean that hazardous convective systems can develop, or unsettled Atlantic perturbations can be strengthened [19]. Rigo and Llasat [20] determined that Mesoscale Convective Systems (MCS) and large multicellular systems are the most common structures responsible for the most significant rainfall episodes in Catalonia. On the contrary, isolated convection or small multicellular systems can produce heavy, localised rainfall that can potentially cause flash floods (in short and torrential streams) and urban floods [7]. To be managed as well as possible, good meteorological forecasts and primary warning systems are required. Numerical weather predictions are usually not accurate enough for such small scales with complex orography, and advanced monitoring systems have limitations as well. New and more advanced decision support systems are needed to provide valuable information in critical situations [1].

In this context, radar data offer good complementary information and can work as an observational system and also as an assimilating source for meteorological mesoscale models [21,22]. Radar networks provide reflectivity composites with wide spatial coverage and a continuous timeline. This information allows the monitoring of the whole life cycle of MCS and also of minor convective structures. As the rainfall amount is usually underestimated by radar, and this fact increases with range and beam blocking [23], a rain gauge network with good coverage provides a complementary source to reproduce small-scale variability in rainfall [24].

The main objective of the present work is to determine if whether storm cells are more concentrated in some areas of Barcelona than in others. In a first step, radar data will be combined with observations from rain gauges to find significant rainfall episodes in Barcelona. A radar-based methodology is developed to identify convective cells in those relevant episodes, and a further study is carried out to localise the areas of the city where convective cells are most frequently located to achieve the objective. The identification and characterisation of storms aim to increase understanding to improve short-term forecasts. The performance of early warning systems will improve in conjunction with better forecasts, reducing the impact of severe weather. 
Section 2 details the region of interest, BCASA water management system, the different data sources and explains the methodology. Then in Section 3, all the different results are shown, and in Section 4, they are discussed. Finally, in Section 5, the conclusions are reached.

\section{Data and Methodology}

This section first describes the region of study and explains the water cycle management system in Barcelona. Then it goes on to share the data sources, and finally, it details the methodology.

\subsection{Region of Interest}

The Barcelona Metropolitan Area (AMB) is placed in the northeast of the Iberian Peninsula, about $120 \mathrm{~km}$ to the south of the Pyrenees (Figure 1a). It covers more than $600 \mathrm{~km}^{2}$, and it is densely urbanised (36 municipalities comprising over 3.2 million people) with very frequent heavy rainfall events. It is naturally limited by the Mediterranean Sea (east), the Collserola mountain range (west), the river Llobregat (south) and the river Besós (north) (Figure 1b). In addition, different hills are within the city. Torrential streams born in the Littoral Mountain range and hills usually experience flash floods in autumn, as a consequence of heavy rainfalls favoured by the orography. Additionally, both of the main rivers surrounding the city have experienced historical catastrophic floods. Barcelona is the second most populated city in Spain, with more than 1,600,000 inhabitants (2018). It covers around $101 \mathrm{~km}^{2}$. Floods are relatively frequent in the city, with more than three pluvial flood episodes per year (109 flood events were registered between 1981-2015 according to [17]). In general, they cause damage to basements and ground floors, power outages, and create problems for urban traffic and public transportation. Floods can even affect historical or heritage buildings, given their locations in flood-prone areas.

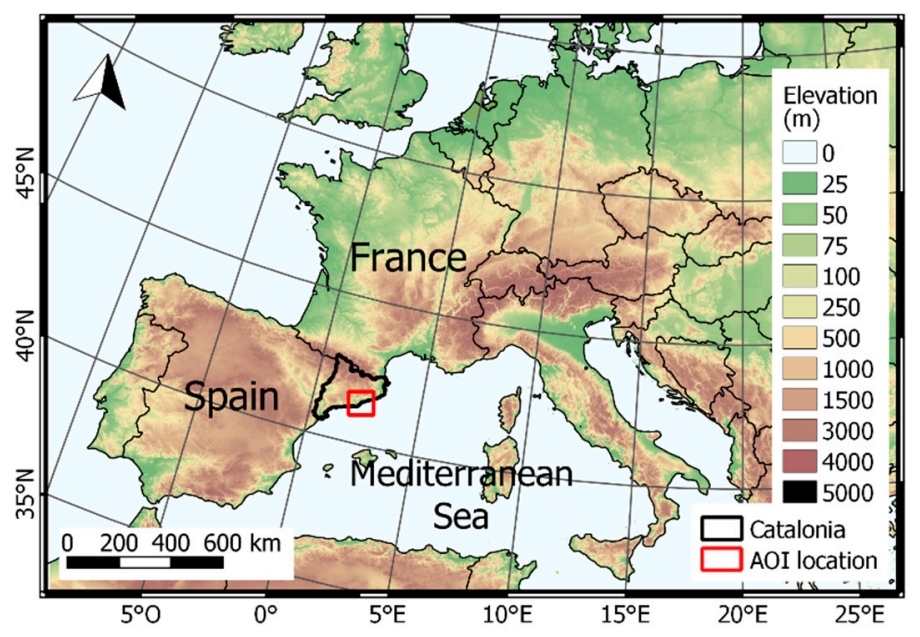

(a)

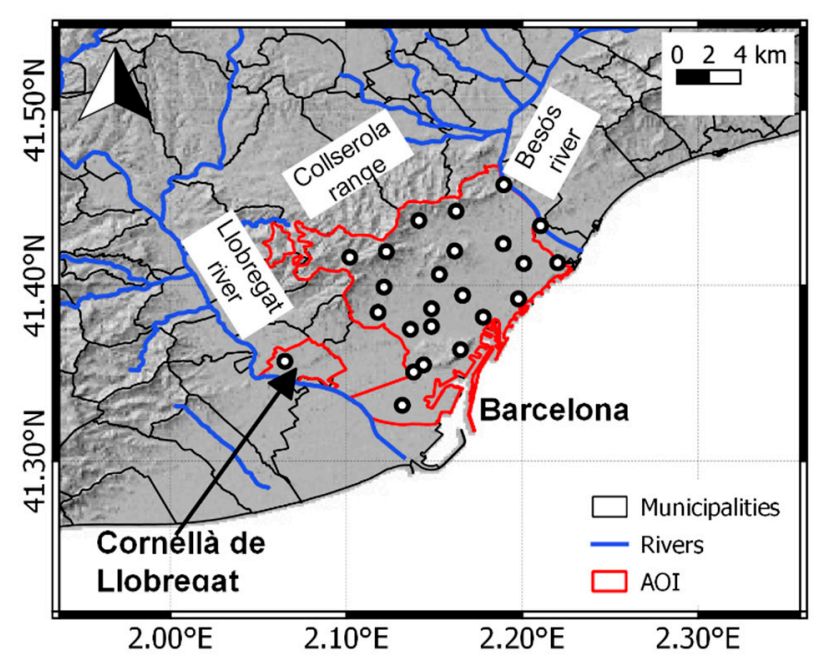

(b)

Figure 1. (a) Geographical location of Catalonia and the Region of Interest (ROI). (b) ROI (in red) and the region selected to analyse radar data. White dots represent the rain gauge network managed by BCASA. The main rivers surrounding Barcelona (Llobregat and Besós) are labelled, as well as the main mountain range (Collserola).

In the present study, the comparison between radar data, surface observations and impact data will focus on Barcelona city and Cornellà (see Section 2.4.1 for more details). The mentioned area will be referenced as the Region of Interest (ROI). Nevertheless, to have a better understanding of the phenomena within the ROI, the analysed area for each episode from a radar point of view has been extended about $10 \mathrm{~km}^{2}$ from the ROI (Figure 1b). 


\subsection{Water Cycle Management and Alert System in Barcelona}

The first attempt to improve resilience to city floods in Barcelona (Spain) was in 1988 with the design of a specific sewerage plan (within the context of the 1992 Olympics) that sought to facilitate water evacuation off the streets by means of building large water collectors near the sea (breakwaters). In 1992, Barcelona City Council created a consortium partnership, Clavegueram de Barcelona S.A. (CLABSA), to complete this task. After some years, on 21 September 1995, a flood caused one death, and the city collapsed (2500 emergency calls, 25 flooded metro stations, 80 incidents in the sewer system, etc.) because of a local daily rainfall of $91.9 \mathrm{~mm}$ and a maximum 5-min rainfall intensity of $235 \mathrm{~mm} / \mathrm{h}$ [25]. That unfortunate flood event showed the need for more actions to improve the management of intense rainfall events in the city. In 1997, BCASA published a new specific sewerage plan for Barcelona (PECLAB'97), diagnosing the drainage problems in the city and proposing a new series of actions for improvement. From 1997 to 2004, a series of slide gates and underground stormwater retention tanks were built, and rain gauges began to be installed in several locations in the city. In addition, a remote system to control the slide gates and water tanks was implemented. Overall, the system was designed to prevent floods for the 10-year event precipitation, and even at some points for a 50-year event [26]. In 2014, Barcelona City Council decided to turn the CLABSA consortium into a public enterprise to manage the entire water cycle in the city: Barcelona Cicle de l'Aigua S.A. (BCASA). They handle all the related water processes: sewerage, rainwater tanks, groundwater system, seawater quality control, flooding risk at riverside parks and rainfall intensity warnings.

Nowadays, BCASA manages 13 underground water tanks and 2 surface flooding areas with a capacity of $477,010 \mathrm{~m}^{3}$. They also monitor real-time rainfall data from their rain gauge network, compounded by 23 Lambrecht and Geónica tipping bucket sensors (with an accuracy of $0.1 \mathrm{~mm}$ ) that cover the entire area of Barcelona (Figure 1b). The forecasting team at BCASA is always informed with the latest weather forecast and the radar weather observations from the Meteorological Service of Catalonia (SMC) along with nearly real-time rain gauge data from the network (5-min updating frequency). The automatic alert system processes the data from the rain gauge network and based on 20-min and 60-min rainfall intensities (maximum and average), it issues five different alert levels for Barcelona ("Nivel de Alerta a Barcelona", NAB) (Table 1). The first three levels act as a warning, so the current automatic protocols are revised by experts, and the different contributors to emergency prevention and mitigation are revised to ensure the situation is being controlled automatically, with no incidents. Level four suggests that Civil Protection should activate the Alert Plan for possible floods in Barcelona. Finally, level five activates an emergency, and the expert committee meets to coordinate the situation in the city. At this point, BCASA contributes as an information provider and experienced consultant.

Table 1. BCASA criteria to activate the alert level in Barcelona (NAB). Levels are based on two precipitation intensity thresholds (20 min intensity, $\mathrm{I}_{20}$ and $60 \mathrm{~min}$ intensity, $\mathrm{I}_{60}$ ). $\mathrm{PAB}=$ Forecast of a possible alert in Barcelona.

\begin{tabular}{ccccc}
\hline & & & \multicolumn{2}{c}{ Rainfall Level } \\
\cline { 3 - 5 } & NAB & PAB & $\begin{array}{c}\text { High Intensity } \\
\text { Indicator }\left(\mathbf{I}_{\mathbf{2 0}}\right)\end{array}$ & $\begin{array}{c}\text { Prolonged Rain } \\
\text { Indicator }\left(\mathrm{I}_{60}\right)\end{array}$ \\
\hline 0 & INACTIVE & 0 & - & - \\
\hline 1 & STANDBY & \multirow{2}{*}{$1 ; 2$} & $0 \mathrm{~mm} / \mathrm{h}\left(\mathrm{T}_{20}>0\right)$ & $0 \mathrm{~mm} / \mathrm{h}\left(\mathrm{T}_{60}>0\right)$ \\
2 & SURVEILLANCE & & $20 \mathrm{~mm} / \mathrm{h}\left(\mathrm{T}_{20}<0.1\right)$ & $10 \mathrm{~mm} / \mathrm{h}\left(\mathrm{T}_{60}<0.1\right)$ \\
\hline 3 & PRE-ALERT & & $30 \mathrm{~mm} / \mathrm{h}\left(\mathrm{T}_{20} \approx 0.15\right)$ & $15 \mathrm{~mm} / \mathrm{h}\left(\mathrm{T}_{60} \approx 0.15\right)$ \\
4 & ALERT & $\geq 3$ & $50 \mathrm{~mm} / \mathrm{h}\left(\mathrm{T}_{20} \approx 0.4\right)$ & $25 \mathrm{~mm} / \mathrm{h}\left(\mathrm{T}_{60} \approx 0.4\right)$ \\
5 & EMERGENCY & & $70 \mathrm{~mm} / \mathrm{h}\left(\mathrm{T}_{20} \approx 1\right)$ & $35 \mathrm{~mm} / \mathrm{h}\left(\mathrm{T}_{60} \approx 1\right)$ \\
\hline
\end{tabular}


The average number of alerts activated per year is between 3 and 4, but it varies from one year to the next. Furthermore, as urban floods in Barcelona have very short time scales and are rapidly solved, the emergency level is rarely activated. The combination of the automatic sewerage and drainage systems, along with an alert protocol, allows a coordinated effort with Civil Protection and authorities when flash floods occur in the city.

\subsection{Data Sources}

\subsubsection{Radar Data from the Meteorological Service of Catalonia (SMC)}

Radar data used in this study belong to the radar network of the Meteorological Service of Catalonia (XRAD). XRAD is composed of four radars distributed in strategic points throughout Catalonia (Figure 2): Puig Bernat in Vallirana (PBE, installed in 2000), Puig d'Arques in Cruilles, Monells and Sant Sadurní de l'Heura (PDA, 2002), la Creu del vent in La Panadella, Montmaneu (CDV, 2003) and La Miranda, in Tivissa-Llaberia (LMI, 2008). Each works on three tasks: one long-range task $(250 \mathrm{~km})$, which operates at a set of elevations that are part of the radar volume with similar characteristics, and two short-range tasks (130-150 km), from which different products are created. Composite products are created from individual radar products. They cover the whole region of Catalonia and its surroundings (Figure 2).

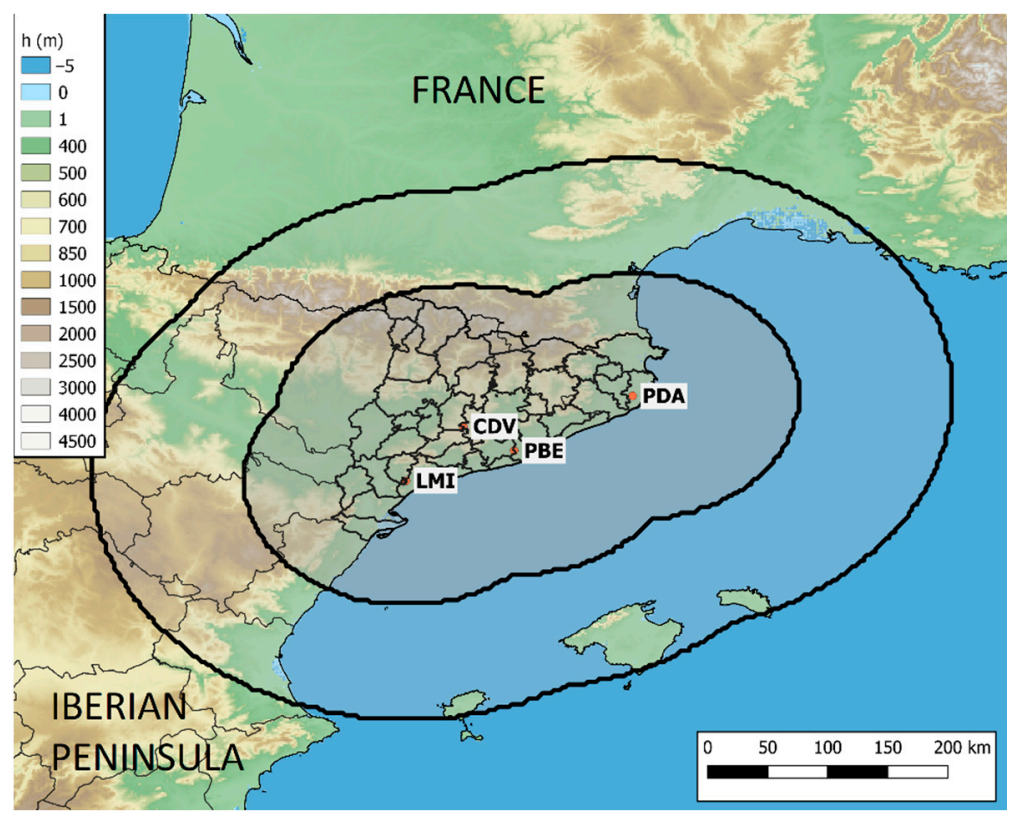

Figure 2. Map showing the north-eastern Iberian Peninsula and southern France. The black outer line represents the long-range coverage of XRAD, and the inner line represents the short-range coverage. The labels and orange dots correspond to each XRAD radar. LMI (La Miranda), CDV (Creu del vent), PBE (La Panadell), and PDA (Puig d'Arques i Cruilles).

All radar products used here are a composition of the images provided by the four different radars. The first one is the daily Quantitative Precipitation Estimation (QPE), corrected with EHIMI (Hydrometeorological Integrated Forecasting Tool) [27] and observational data from the Automatic Weather Stations network of the SMC (XEMA). It is a short-range product with $1 \times 1 \mathrm{~km}^{2}$ spatial resolution. Data files have been available in 'GeoTIFF' format since 2013. In a second stage, to identify convective cells, the maximum surface reflectivity compositions, and short-range reflectivity compositions on 10 vertical levels, CAPPIs (Plan Position Indicator of Constant Altitude), are also used. This product has a vertical extension between $1 \mathrm{~km}$ and $10 \mathrm{~km}$ (by $1 \mathrm{~km}$ ) and has a time resolution of $6 \mathrm{~min}$ and a spatial resolution of $2 \times 2 \mathrm{~km}^{2}$. Considering all vertical levels available 
adds more robustness to the method when identifying convective cells than when only considering the lowest levels (see Section 2.4.3).

\subsubsection{BCASA Rain Gauge Network and Database}

As mentioned in Section 2.2, the rain gauge data from the BCASA network (Figure 1b) are stored in a database. As the network is composed of tipping bucket devices, the information is stored when the bucked fills up and turns over. This information must be converted to minute intensities or hourly rainfall accumulations, depending on how it will be applied. Since 2011, there has also been a separate database with post-event rainfall reports for all the different episodes that have exceeded the rainfall volume of $1 \mathrm{~mm}$. This second database includes for each episode the date of occurrence, daily average and maximum precipitation, average and maximum 20-min and 60-min intensities and NAB (Table 1). When the NAB reaches or exceeds level 3, information about the related incidents is requested by Barcelona City Council and is also included in the database. These incidents are usually related to the sewer system, but they also include flooding on streets, in the metro and basements.

Hourly rainfall data from the different stations of the rain gauge network were used in the study to calculate 24-h rainfall accumulation. These data were cleaned and prepared in advance for the purposes of this study. The rainfall reports were also used to classify rainfall events in Barcelona into different categories according to their impact by means of NAB.

\subsection{Methodology}

Figure 3 shows the different steps followed in the present study. In the following subsections, every process is explained in greater detail.

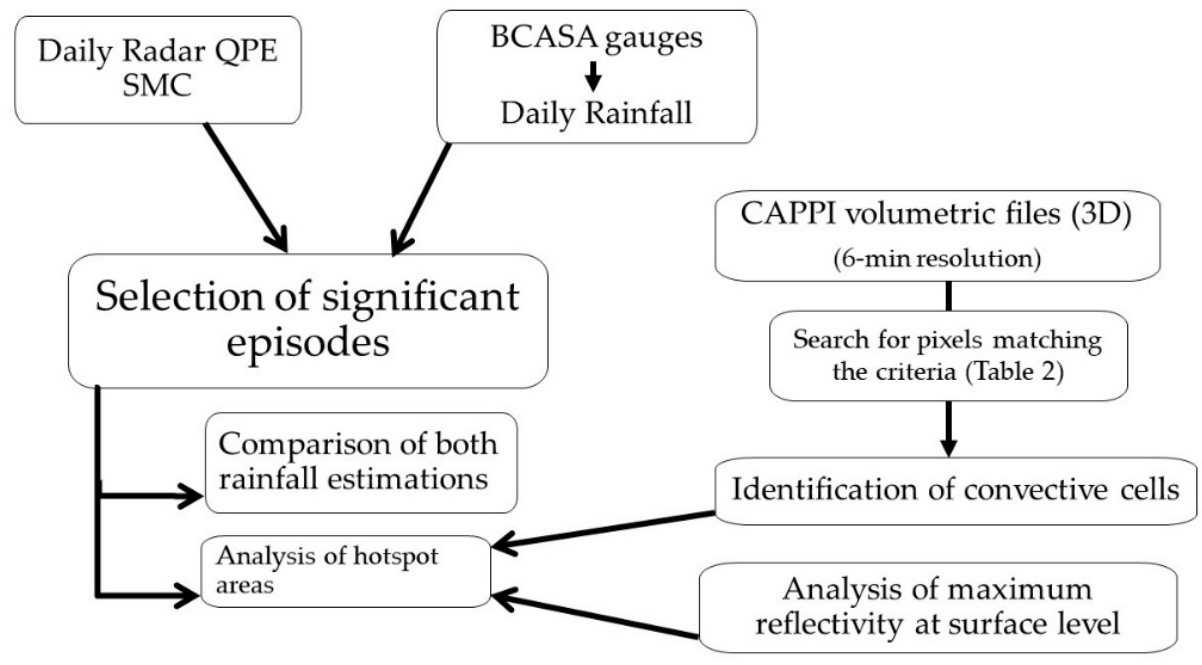

Figure 3. Conceptual scheme of the followed methodology.

\subsubsection{Database Creation: Significant Rainfall Episodes inside ROI}

The first objective was to identify all the significant rainfall episodes within the ROI (cities of Barcelona and Cornellà) that were recorded between April 2013 to December 2018. The reason why it did not start in January is because the SMC started to generate volumetric georeferenced radar files (with the actual format) at the beginning of 2013, but during the first few months, some adjustments had to be made to obtain good quality data. Therefore, the first months of radar data were not used.

For the purposes of this study, a significant rainfall episode was defined as a single rainfall day in which a minimum of $10 \mathrm{~mm}$ of accumulated rain was exceeded at a given point. Rainfall accumulations were computed every day from 00:00 UTC to 23:59 UTC. If the precipitation continued after 23:59 UTC, two different episodes were defined. Fol- 
lowing these criteria, episodes were identified from radar QPE (Quantitative Precipitation Estimation) computed over $24 \mathrm{~h}\left(\mathrm{P}_{\max }\right)$ at a pixel resolution of $1 \times 1 \mathrm{~km}^{2}$. The identification of significant rainfall episodes was also carried out independently by selecting the days that met the criteria from the rain gauge network of BCASA. Episodes obtained from both sources were then compared. If episodes did not appear in both lists, an analysis was carried out to determine if the rainfall within the ROI was significant or if it was an inaccuracy in the data from one of the systems.

NAB criteria from BCASA were incorporated (Table 1) to analyse the episodes that caused major stress to the city in greater detail. A sub-selection of episodes for which BCASA issued an NAB alert level greater than or equal to three was considered for the analysis. Furthermore, to have a more complete view of the impact on the city, reported incidents by the Barcelona City Council were also incorporated.

\subsubsection{Comparison of Rain Gauge Data and Radar Data for Rainfall Episodes}

Rain gauge data were only available for the specific sites where devices are installed. So, when comparing data from the radar network, radar QPE values must be extracted for each episode on the same coordinates (longitude and latitude) where the BCASA rain gauges are located. Using similar statistics as Trapero et al. [23,28], the Bias (expressed in $\mathrm{mm}$ ) and the Root Mean Square Factor (RMSf) were calculated for each rainfall episode:

$$
\begin{gathered}
B I A S=\frac{1}{N} \sum_{i=1}^{n} 10 \times \log \left[\frac{Q P E_{\text {rad }}}{Q P E_{\text {gau }}}\right] \\
R M S f=\sqrt{\frac{1}{N} \sum_{i=1}^{n}\left(\ln \left[\frac{Q P E_{\text {rad }}}{Q P E_{\text {gau }}}\right]\right)^{2}}
\end{gathered}
$$

where $N$ is the number of points where either $Q P E_{\text {rad }}$ or $Q P E_{g a u}$ are greater than $0.1 \mathrm{~mm}$. The RMSf is a dispersion indicator, so it should be larger whenever the episode has high variability. That will happen if the rainfall episode is highly convective. Otherwise, if Bias is close to zero, radar and rain gauges agree in rainfall accumulations, while Bias values smaller or greater than zero will indicate either that the radar underestimated or overestimated the rainfall amounts, respectively.

\subsubsection{Analysis of Storm Hotspots with Radar}

Nowadays, there is wide literature about weather radar applications, such as works focused on forecasting [29-31], some others about the characteristics of meteorological patterns [32] or about the identification of convective structures [29,33]. In this last case, there are strategies for identifying storm structures from levels near the surface $[32,34,35]$ and others with a higher degree of complexity that use volumetric thresholds and can require a long processing time $[29,33]$. In this work, two approaches were explored to identify the sites within the ROI where intense rainfalls are most prone to occur. These methods have low computation requirements and can be run over a great number of rainfall events, as well as in an operative way. The first approach was an analysis of radarmaximum surface reflectivity products, while the second was based on CAPPI products.

The first approach analyses radar data files of $24 \mathrm{~h}$ maximum reflectivity intensity at surface level. For each radar file (maximum values of surface reflectivity for an episode), three different thresholds were established: $30 \mathrm{dBZ}, 45 \mathrm{dBZ}$ and $55 \mathrm{dBZ}$. For each episode and threshold, a density map of threshold exceedance was generated. The resulting products show the number of episodes that surpassed a threshold at a pixel resolution of $1 \times 1 \mathrm{~km}^{2}$. In this way, the most frequent locations where surface reflectivity values were high could be identified.

As has been mentioned, the second approach consisted of establishing a fast methodology to do the identification of convective cells. It was applied for all the significant episodes. For this task, CAPPI products from XRAD were used. As explained in Section 2.3.1, these 
are volumetric files containing different vertical levels of reflectivity at a time resolution of $6 \mathrm{~min}$. The algorithm was programmed as an R script. For each time step, the following procedure was applied:

1. The script searches for all the pixels $\left(2 \times 2 \mathrm{~km}^{2}\right)$ inside Barcelona and the surrounding area (a radius of about $10 \mathrm{~km}$ from the limits of the city) that comply with these three criteria: (1) the maximum reflectivity value surpasses the threshold of $35 \mathrm{dBZ}$, (2) reflectivity achieves at least $30 \mathrm{dBZ}$ above $3 \mathrm{~km}$ of altitude, and (3) at least five contiguous pixels match the previous conditions.

2. All the adjacent pixels that meet these conditions will be grouped into a single convective cell. It is possible to identify other convective cells in the same image as long as the distance between them is at least one pixel.

3. The information that characterises each convective cell is stored in a text file. This information covers the date of the event, the time when the cell was detected, the longitude and latitude coordinates of the centre of the cell, how many pixels it is made of, its overall area, and if there were other cells at the same time inside the analysed region.

The restriction of a minimum number of pixels to meet the reflectivity conditions is imposed to avoid the consideration of isolated reflectivity maximums without enough organisation as convective storm cells.

Both [29] or [33] also proposed a minimum size for convective cells and used CAPPI values, but they had used more complex $3 \mathrm{D}$ algorithms to identify them. They both consider a wider range of thresholds at different vertical levels. They are useful for nowcasting operations [33] as well as to analyse anomalous movements [31], but in coastal regions, where shallow convection is prone to occur, those complex $3 \mathrm{D}$ algorithms can be too restrictive to characterise significant storms. Therefore, the described algorithm seems more appropriate to this study. Even when it is based on simple restrictions, it considers the altitude of convective structures (simplified 3D algorithm), which makes it more robust than other $2 \mathrm{D}$ algorithms [32,35]. The simplifications make the methodology computationally efficient, which allows the analysis of a very large number of episodes in a short time.

\section{Results}

\subsection{Database Creation: Rainfall Episodes}

Between April 2013 and December 2018, 163 rainfall episodes that met the criteria (Section 2.4.1) were found in both data sets (XRAD and BCASA networks). However, there were 58 additional episodes detected only by radar. For those episodes, a deeper analysis was carried out, concluding the following:

- In 38 cases, BCASA rainfall observations registered precipitation between 1 and $10 \mathrm{~mm}$ at some places.

- In 6 cases, rainfall recorded by BCASA network was under $1 \mathrm{~mm}$, but radar showed a congruent rainfall field.

- In a further 14 cases, the rainfall field barely crossed the border of ROI, or rainfall occurred mainly over the sea. The algorithm used to find the significant episodes from radar data has classified the day as a significant rainfall episode, but the detailed analysis revealed that it was not significant at all. These cases were not included in the final list of episodes.

The differences found in the first two types of missing episodes may be due to the different spatial coverage of both types of sensors. Given that the radar has a homogeneous coverage in the study area, these 44 cases were considered good, reaching a total number of 207 significant rainfall episodes in the ROI between April 2013 and December 2018 (shown in Appendix A, Table A1).

Major differences in the number of episodes between both sources were shown by the end of spring and the beginning of autumn: a difference of 9 episodes in June, 12 in 
July, 11 in September and 12 in October. Summer events are usually very convective, short and local, and for this reason, they may not have been detected by the rain gauge network. Despite the good spatial resolution of the rain gauge network, convective precipitation can be highly localised and not detected by any rain gauge [36]. Moreover, anomalous propagation of the radar beam under certain atmospheric conditions [37] or other anomalous echoes that may identify precipitating nuclei when they do not exist can be considered.

The yearly distribution of these significant episodes is shown in Figure 4. December was the month with the least episodes, and September had the most. Overall, from February to August, there were between 12 and 18 episodes per month. It was during autumn (from September to November) when the greater number of episodes was found.

Climatology 2013 - 2018 of Significant episodes in ROI

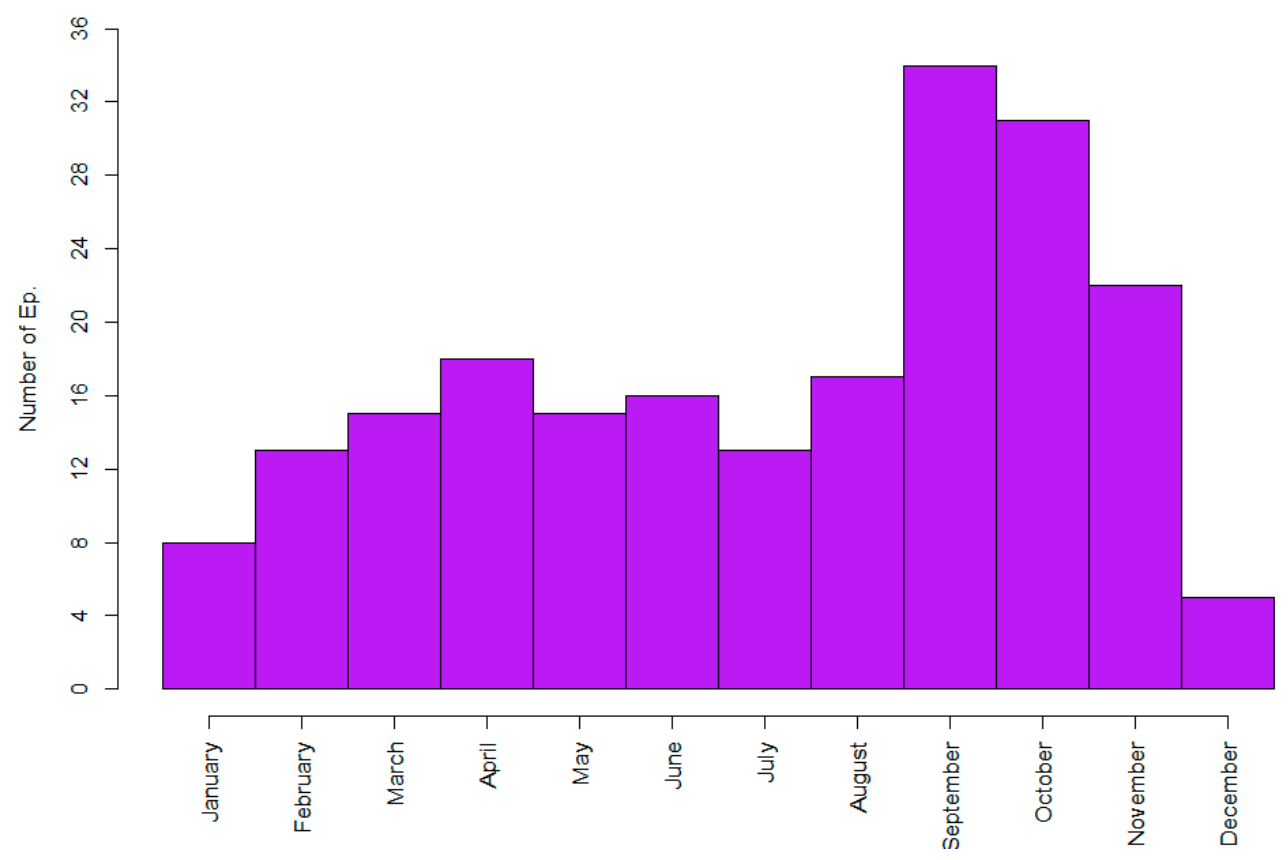

Figure 4. Monthly evolution of significant rainfall episodes from April 2013 to December 2018.

The distribution along the year of significant rainfall episodes in this work is consistent with previous studies carried out in the same region for longer periods. In Catalonia, there is a large spatial and temporal variability in terms of the annual rainfall cycle, with typically short thunderstorms during summer and spring and larger events during late autumn and winter [20,36]. In addition, Barrera et al. [8] and Cortès et al. [5] showed that most of the floods in Barcelona are concentrated between the end of summer and autumn, with the maximum number of episodes per month in September.

When filtering rainfall episodes using the NAB level issued by BCASA, that were greater than or equal to 3, there were 64 cases in the studied period (Table A2 in Appendix A). Analysing the dates for the episodes with the highest alert level $(\mathrm{NAB}=4)$ in Table A2, one observes they were not uniformly distributed throughout the year. They seemed more likely to occur from July to November, but since there were only 17 cases over a 6-year period, it was not possible to determine any kind of trend. Referring to those with NAB equal to 3, the probability of occurrence was higher from May to November, with a maximum average of cases per month in August and September. These results are consistent with [36]. According to the data, there was no evidence of an upward trend for episodes with greater $N A B$, but again, the study period is too short.

$\mathrm{NAB}$ is an alert indicator, but it is not directly related to the impacts in the city. For this reason, incidents reported by Barcelona City Council were also included (Table A2 in Appendix A). It stands out that not all the episodes with the highest precipitation values 
had the most reported number of incidents. In fact, incidents were only reported for 28 of them. The first four episodes that reported the largest number of events took place in the last year of the study (2018). From October to November of the same year, there was an unusually high occurrence of extraordinary rainfall episodes in the city. In general, $\mathrm{NAB}=4$ cases had more reported incidents per episode than $\mathrm{NAB}=3$ ones. These episodes were mainly concentrated in November, March, September and October. Considering the total number of incidents per year, 2018 (with 353) was the most reported year. The second was 2014 (174), then 2017 (75), 2016 (58), 2015 (17) and finally 2013 (15). Since 2013, there has been an increasing trend in the number of incidents per year, but this could be caused by the reporting methodology. In the past, Barcelona City Council gathered water-related incidents through phone calls from citizens. Today, BCASA manages the database and has changed the way in which information is obtained. They want to obtain a greater variety of rain-related incidents in order to create a more robust database. Table 2 shows the annual distribution of the rainfall episodes with reported incidents. In all the winter seasons, no episode was reported with these characteristics. The episodes with the highest alert level were most concentrated in the autumn seasons. Nevertheless, the number of those events reported during summers was also significant. Overall, there was a similar number of cases with $\mathrm{NAB}=3$, spread over the spring, summer, and autumn periods.

Table 2. Seasonal distribution of episodes with the most impact in Barcelona based on the reported incidents from April 2013 to December 2018. The seasons considered were winter (December, January, and February), spring (May, April, and March), summer (June, July, and August) and autumn (September, October, and November). The values shown are the number of episodes for each category (NAB equal to 3 or 4) per season, observed maximum, minimum and median values for maximum cumulated precipitation in an episode for each season, and 25 and 75 percentiles for the same variable for each season.

\begin{tabular}{|c|c|c|c|c|c|c|c|c|c|c|c|c|}
\hline \multirow{3}{*}{ Season } & \multicolumn{6}{|c|}{ NAB 3} & \multicolumn{6}{|c|}{ NAB 4} \\
\hline & \multirow{2}{*}{ No. of Ep. } & \multicolumn{5}{|c|}{$P_{\max 24 h}(\mathrm{~mm})$} & \multirow{2}{*}{ No. of Ep. } & \multicolumn{5}{|c|}{$P_{\max 24 \mathrm{~h}}(\mathrm{~mm})$} \\
\hline & & $\operatorname{Max}$ & Min & Med & $25 \%$ & $75 \%$ & & $\operatorname{Max}$ & Min & Med & $25 \%$ & $75 \%$ \\
\hline Winter & 0 & - & - & - & - & - & 0 & - & - & - & - & - \\
\hline Spring & 4 & 33.00 & 12.40 & 26.85 & 26.23 & 38.65 & 2 & 101.20 & 57.80 & 79.50 & 68.65 & 90.35 \\
\hline Summer & 3 & 26.15 & 30.35 & 35.60 & 65.80 & 28.80 & 5 & 65.80 & 28.80 & 44.40 & 39.40 & 55.3 \\
\hline Autumn & 5 & 40.30 & 37.50 & 53.30 & 133.40 & 28.10 & 9 & 133.40 & 28.10 & 94.90 & 45.50 & 101.2 \\
\hline
\end{tabular}

After analysing the maximum cumulative precipitation (BCASA network) on the previously sub-selected episodes with reported incidents (Table 2), the ones with NAB equal to 3 indicated a maximum between 12.45 and $40.30 \mathrm{~mm}$. Episodes with NAB equal to 4 showed a wider range of values: there were episodes with maximums from 28.10 to more than $110 \mathrm{~mm}$ (cumulative rainfall over $24 \mathrm{~h}$ ) and an exceptional case with $133.4 \mathrm{~mm}$. It must be noted how on some intense rainfall episodes, few or no incidents were reported, but also, episodes with a significant impact on the city and without large rainfall accumulations were also found. Table 2 also displays the seasonal variability of maximums collected in those rainfall episodes. Higher maximum values were observed in both the spring and autumn seasons. Looking at the $75 \%$ percentile, episodes with $\mathrm{NAB}=3$ had larger rainfall accumulations in spring, while for those with $\mathrm{NAB}=4$, the larger accumulations occurred during autumn.

When trying to establish trends and patterns in terms of impacts on the city of Barcelona, it seems that the number of episodes with reported incidents shows a decreasing trend over the analysed period, except for 2018, where an unusually high number of extraordinary rainfall episodes compromised the normal running of the city. There is no doubt that rainwater management systems (such as rainwater tanks) and correct maintenance of the sewerage system, coordinated by BCASA, have had an important role in decreasing damage in the city [8], which again highlights the importance of early warning systems in order to be prepared against the most significant events. 


\subsection{Comparison of Rain Gauge Data and Radar Data for Rainfall Episodes}

For each episode on the database, maximum cumulative precipitation on rain gauge locations from radar products and rain gauge data were compared, as explained in Section 2.4.2 of methodology. For the 207 cases presented in the previous section, the overall difference (BIAS) was calculated, as well as the RMSE. In Figure 5, the seasonal distribution of BIAS and RMSE is shown. Episodes with no observational rain gauge data ( 3 of them) were counted as radar overestimation cases. For some months (from May to October), the radar struggled to reproduce the observations from the BCASA network, and a trend to rainfall overestimation was observed. This is a consequence of using a single Z-R relationship throughout the year. Radar QPE calculations do not distinguish the water phase, but when there is ice in the clouds, the reflectivity values are much higher than usual, and the resulting QPE may be much higher than the real figures. This applies to hail episodes (relatively frequent in Catalonia and the ROI [29]).

P24h Radar vs rain gauges networks

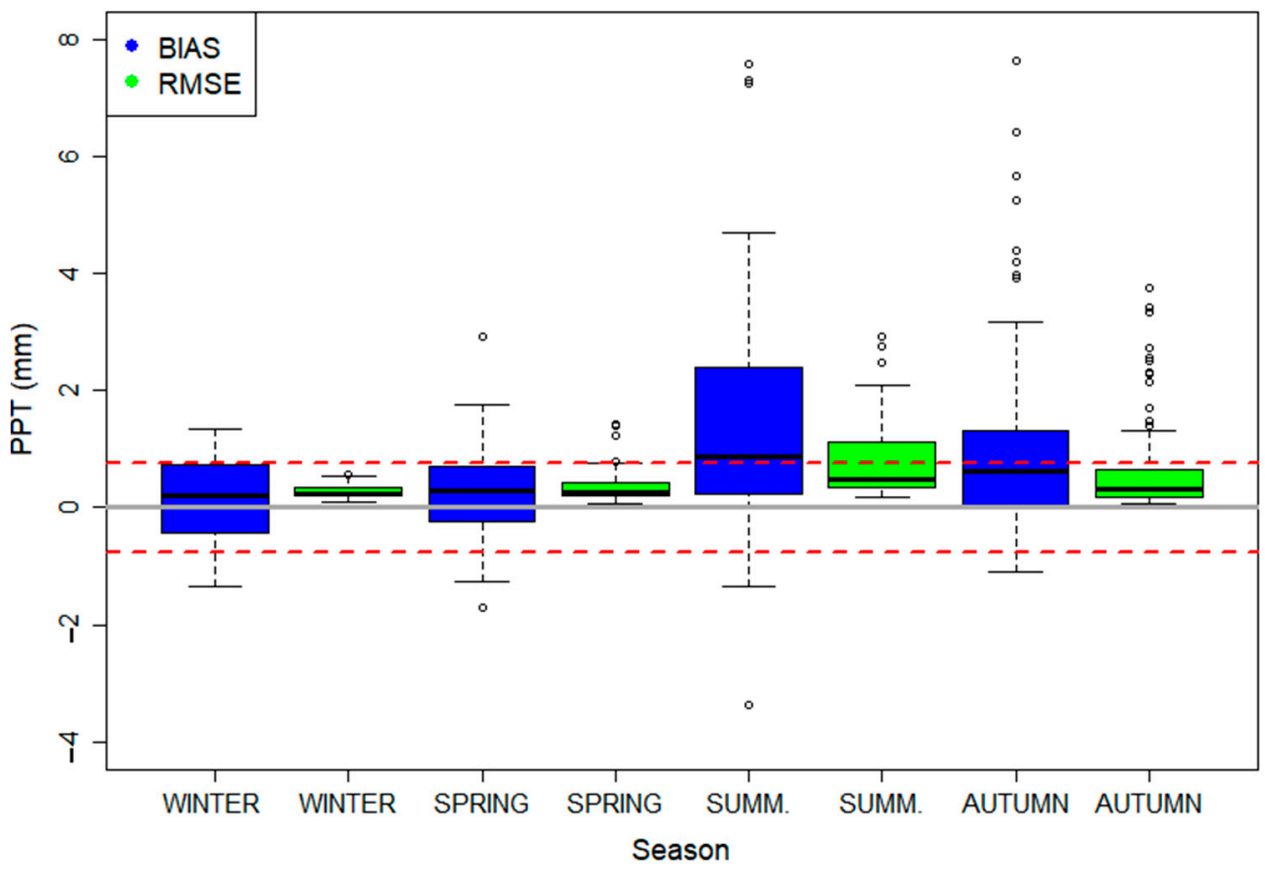

Figure 5. Seasonal distribution of the calculated $24 \mathrm{~h}$ rainfall BIAS and RMSE between XRAD products and the BCASA rain gauge network for the 207 rainfall episodes in the ROI.

SMC had previously calculated the overall bias of its radar network in Catalonia. For each episode, they compared point by point, the accumulated precipitation with the observations from an automatic weather station network (XEMA), also managed by the SMC. From June to September, SMC gets an overall positive bias, which is consistent with the results in Figure 5. But in this work, the positive bias also extended to October. This is also consistent with the SMC calculations, as they also documented a positive bias along the coastline of Catalonia from September to November. However, overall, this bias was compensated with a negative bias inland (not shown).

By comparing maximum cumulative precipitation values from both sources for episodes with NAB greater than or equal to 3, a trend towards radar overestimation can be observed. A larger study with a greater number of episodes with the same characteristics is needed to analyse this tendency in more detail. With the available data, it seems XRAD has a better ability to reproduce more accurate maximum values when NAB is equal to 3 than when it is equal to 4 . It is also important to note that the rain gauge network is not as dense as the radar resolution data, so for highly convective precipitation with wide intensity gradients, radar measurements may be more accurate [24]. 


\subsection{Storm Hotspot Analysis with Radar}

3.3.1. Analysis of Surface Maximum Reflectivity Maps

Following the first approach, the frequency of exceeding a surface reflectivity of $30 \mathrm{dBZ}$ in significant rainfall episodes is shown (Figure 6). The procedure was repeated two more times, raising the target threshold to surpass a surface reflectivity of $45 \mathrm{dBZ}$ (Figure 7) and once again for $55 \mathrm{dBZ}$ (not shown).

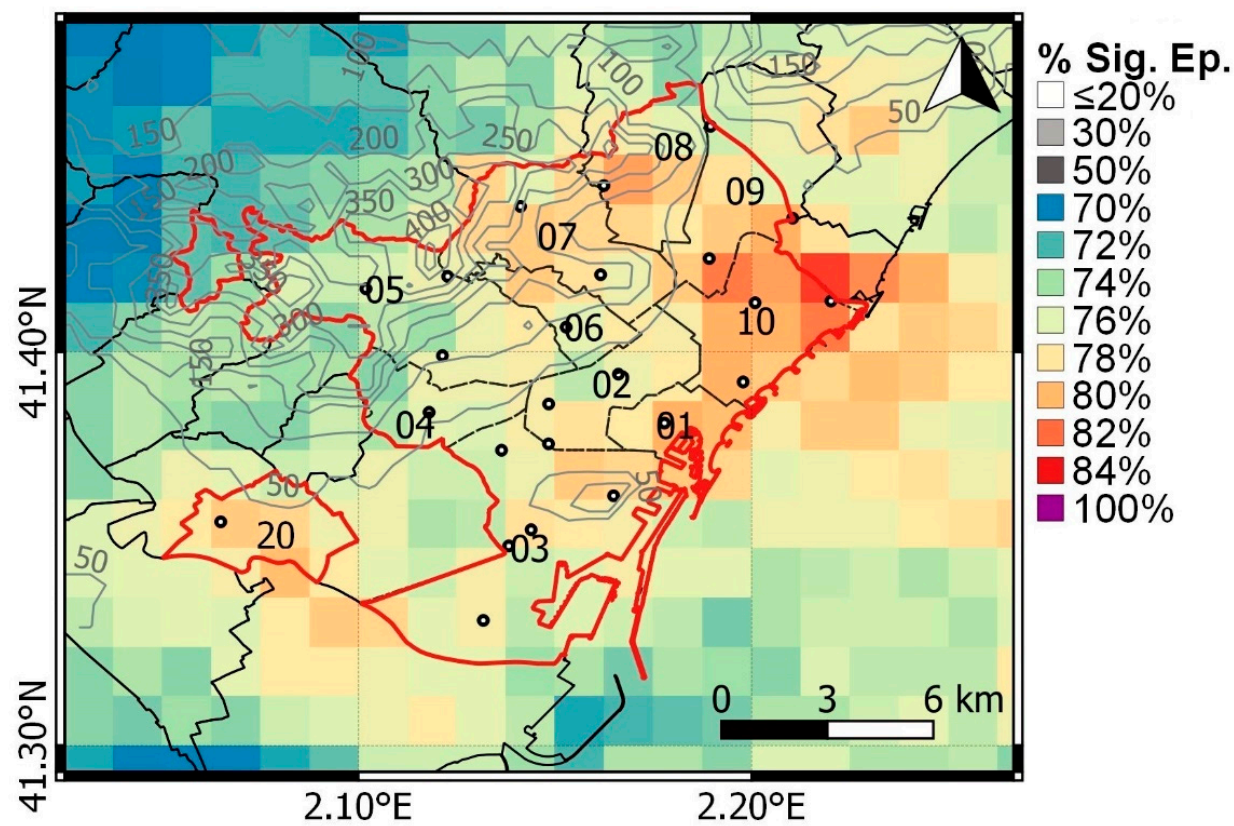

Figure 6. Distribution of maximum surface reflectivity surpassing $30 \mathrm{dBZ}$. It shows the frequency on each pixel for significant rainfall episodes. The grey contour lines show regions of a constant height (m). The red solid line outlines the ROI. Inside, black solid lines divide the different districts labelled as follows: 01-Ciutat Vella, 02-Eixample, 03-Sants-Montjuïc, 04-Les Corts, 05-Sarrià, 06-Sant Gervasi, 07-Horta-Guinardó, 08-Nou Barris, 09-Sant Andreu, 10—Sant Martí, and 20—Cornellà de Llobregat.

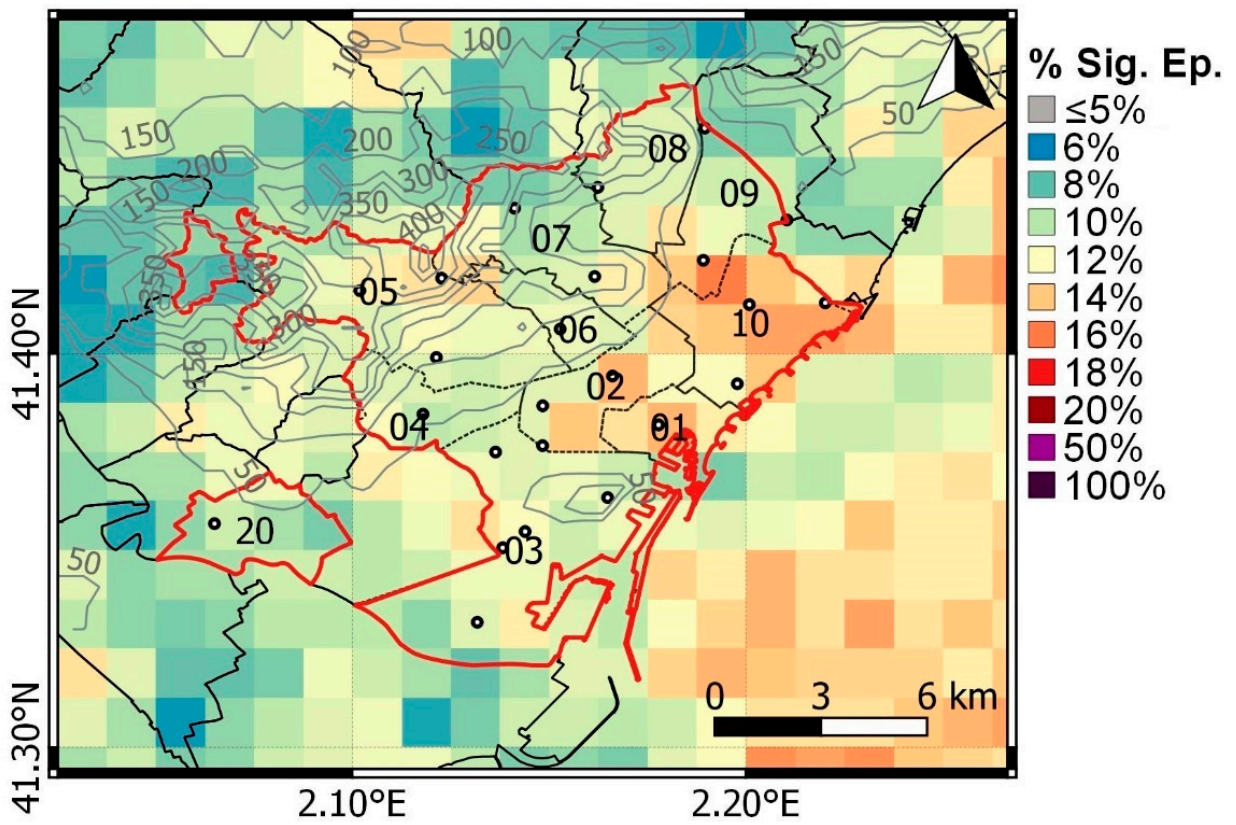

Figure 7. Same as Figure 6, for $45 \mathrm{dBZ}$. 
Figure 6 shows the greatest concentration of pixels with the highest frequencies in the north-eastern part of the ROI, mostly near the coast. In the Sant Martí district, for more than $81 \%$ of the cases, maximum surface reflectivity exceeded $30 \mathrm{dBZ}$. Another hotspot can be observed in Ciutat Vella and Nou Barris (for more than $80 \%$ of significant episodes). Furthermore, Cornellà de Llobregat, Sant Andreu and Horta-Guinardó surpassed the threshold in up to $80 \%$ of the studied episodes. When repeating the procedure with the $45 \mathrm{dBZ}$ threshold, the number of significant episodes exceeding the threshold significantly decreased (Figure 7), but three different areas had a higher frequency of episodes surpassing the threshold. This occurred in the Sant Martí and Sant Andreu districts, with maximum frequencies up to $16 \%$, in Ciutat Vella and Eixample with frequencies around $15 \%$, and locally in the north-eastern part of Sarrià with $14 \%$ of cases. On the other hand, surface reflectivity values above $55 \mathrm{dBZ}$ were rarely achieved inside the ROI, just in $1 \%$ of the significant episodes analysed for some of the pixels inside Sarrià and Ciutat Vella districts (not shown).

\subsubsection{Analysis of Convective Cells on Rainfall Episodes}

The second approach was applied to the 207 rainfall episodes to identify convective cells within the area (ROI and a surrounding $10 \mathrm{~km}$ buffer). As a result, more than 8000 centroids of convective cells from 189 cases were obtained. Figure 8 shows the spatial distribution of these centroids inside ROI. A higher density of centroids was identified in four different zones:

- In the north-north-eastern part of the city, mostly affecting the Nou Barris and HortaGuinardó districts, and the northern part of the Gràcia district.

- Right in the middle of the city, affecting the Eixample district, southern Gràcia and northern Sants-Montjuï.

- The west part of the municipality of Cornellà de Llobregat.

- In the northwest of the Sant Martí district.

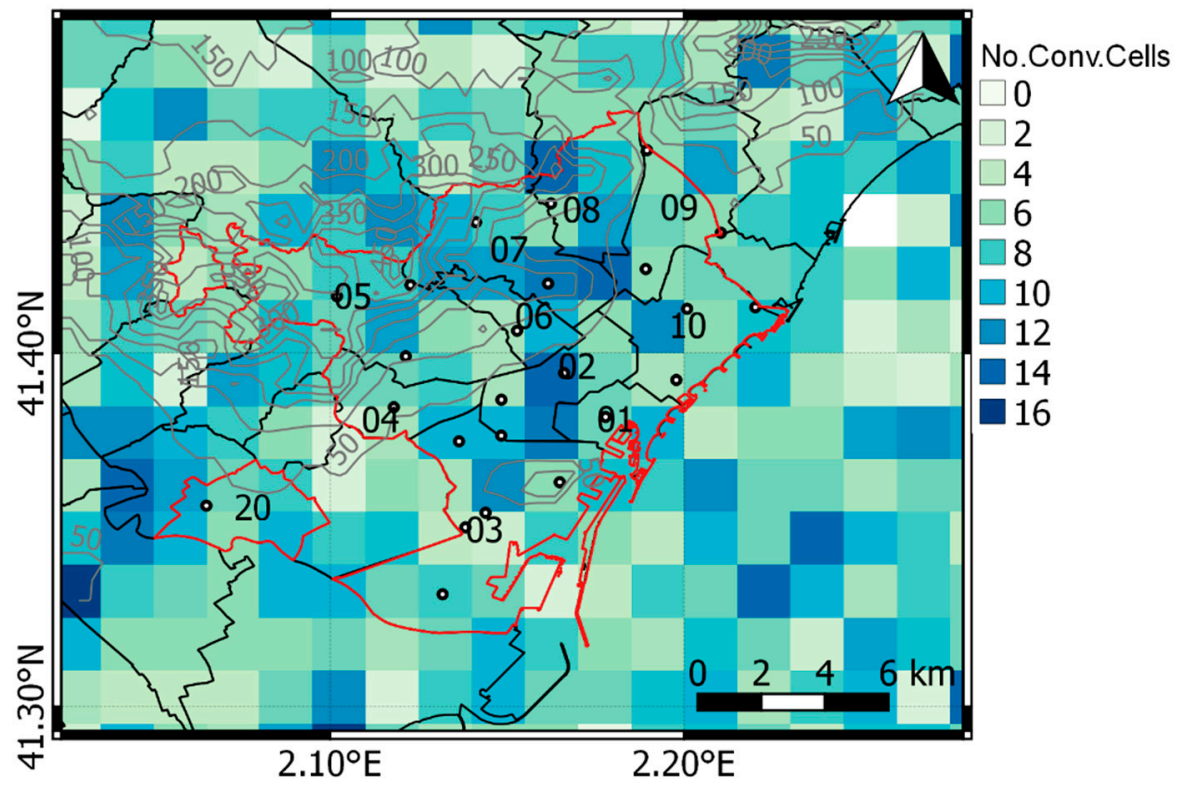

Figure 8. Distribution of centroids of convective cells for significant episodes. The numbers refer to Barcelona districts, and they are detailed on Figure 6.

Some of the mentioned districts also had high rates of surpassing the $45 \mathrm{dBZ}$ threshold for surface reflectivity. Nevertheless, when comparing spatial distributions between Figures 7 and 8 , they were not so similar. While maximum surface reflectivity values over $45 \mathrm{dBZ}$ were more prone to occur near the coastline, the centroids of storm cells tended to concentrate more inland, right in the middle of the studied area. This means that, even 
when the intensity of radar reflectivity is related to rainfall intensity, it is not the only factor to monitor to prevent flash floods.

For all the episodes with an NAB greater than or equal to 3, one or more convective cells were found by the algorithm. When analysing the hourly distribution of convective cells for these episodes, two maximums were obtained:

- Around 07:00 UTC time (in the morning), a relative maximum.

- From 15:00 to 20:00 UTC time (afternoon), reaching the peak at 17:00 UTC.

These results are consistent with a diurnal convection cycle, with the first maxima right after convection starts due to diurnal heating and the second one after the peak, causing convection to develop. Nonetheless, it is worth mentioning that a lower frequency of convective storm cells was expected during the night, especially during the early hours of the day. One possible explanation could be related to anomalous propagation on the radar display. During steady nights where a temperature inversion is more likely, anomalous propagation may generate false echoes of intense reflectivity, and the effect is most prone to occur in coastal regions $[37,38]$. Those echoes can be wrongly identified as storm cells.

Although the ensemble of episodes with greater NAB was limited, Figure 9 shows the spatial distribution of centroids (a) and the same for episodes with reported incidents.

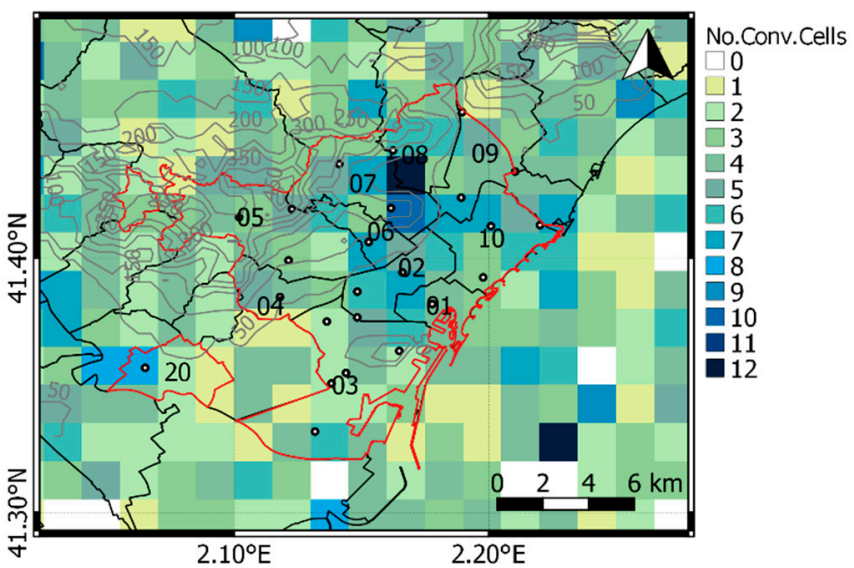

(a)

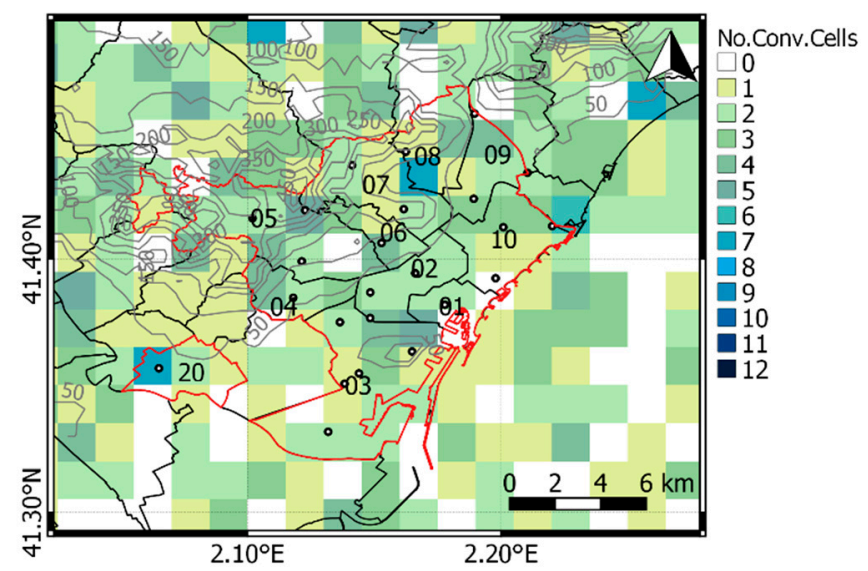

(b)

Figure 9. Distribution of storm cells centroids across all episodes with NAB 3 or 4 (a) and for episodes with the mentioned NAB levels and reported incidents (b).

When comparing Figures 8 and 9, some common features are revealed. Pixels with the highest concentrations of centroids were located on the lower side of complex terrain, with a higher number of centroids per pixel in the middle of the ROI. Darker pixels on Figure 9a are similar to those in Figure 8, but with a smaller number of centroids per pixel and a larger gradient between the most affected districts and the ones that were not so affected. Both figures agree that most of the centroids were found in the districts of Nou Barris, Horta-Guinardó, Eixample and Sants-Montjuïc. On the other side, Figure 9b highlights maximum concentrations on Cornellà and on the border between Nou Barris and Horta-Guinardó districts. In addition, some pixels had slightly higher concentrations of centroids on the southern part of Gràcia, on Sarrià and les Corts and on the border between Montjuïc, Ciutat Vella and Eixample.

\section{Discussion}

Rainfall episodes with a greater impact on Barcelona are not the only factor linked to flood hazards, but vulnerability and exposure also play an important role [3]. Between 1351 and 2005, 85 flash floods and pluvial floods seriously affected the city of Barcelona [8]. The analysis of this long period showed a positive trend of extraordinary floods from 
the middle 19th century until the first years of the 20th century, that was mainly due to the walls' destruction that partially acted as a protection in front of flash-floods; urban planning that did not include a suitable waste and drainage systems; the great population increase (from 1,555,236 in 1950 to 3,213,775 inhabitants in 2015) and the change in uses of soil [6]. The comparison between land use maps between 1956 and 2009 shows that around $80 \%$ of the agricultural soil in the area analysed was substituted by urban surfaces and the road network (increase of more than 225\%) [5]. As a consequence of this change in the uses of the soil, the runoff in Barcelona increased 19\% for this period. The improvements in sewerage systems and flood prevention infrastructures that were introduced in the 1990s changed the sign of this trend. Although nowadays it is negative, anomalous years can be recorded. In this sense, 2018 was an anomalous year with the greatest number of extremely intense rainfall episodes and reported incidents of the analysed period.

Identifying rainfall episodes with a combination of both XRAD and BCASA information seemed a good approach since considering a single source can lead to the detection of some non-real rainfall episodes. During the winter, XRAD had good agreement with rain gauge data about maximum cumulated precipitations in Barcelona. However, throughout May to October, radar showed higher amounts of precipitation.

Greater concentrations of convective cell centroids were identified on the lower side of the complex orography of Barcelona. This distribution did not exactly match with the locations more prone to surpass $45 \mathrm{dBZ}$ (along the coastline). Some intense storms may not have high-intensity values of reflectivity, but still, they may have a high impact. It can be thought that the convective maxima near the sea are developed by the formation of convergence lines over the sea or in the coast, perhaps between the breeze and the maritime flow, while the maxima in the interior are associated with blockages and orographic forcing.

Although the pixels with the highest concentrations of centroids were different in the three different selections of episodes (Figures 7-9), it is clear from Figures 8 and 9 that the complex topography bounding the ROI plays a major role in the location of the storms linked to the studied centroids. The importance of small-scale topographic obstacles as a triggering factor for storms has been widely proved by several studies and models $[6,39]$ as well as the influence of the sea and the topography on the motion of the storm systems [39]. Nevertheless, it is also important to highlight that rainfall patterns do not only respond to the influence of topography [40].

Finally, from a hazard point of view, urban flash floods response is a combination between the spatial-temporal distribution of precipitation, local drainage system and local relief inside the city [41]. In this study, only meteorological hazards and impacts were considered, but for a wider study on urban floods, it is essential to include the different urban land uses (natural drainage) and their runoff coefficients [42,43] as well as the drainage system. However, it must be said that the study by Cortès et al. [5] showed that although land uses can be very different in the Barcelona Metropolitan Area, within the ROI they are essentially non-draining ones. The undergrown water retention system and sewerage management of BCASA have been designed according to these characteristics, and they are a key point to avoid fatalities and major economic losses in the city.

\section{Conclusions}

During this research, a new and relatively easy methodology was established to identify convective cells in the city of Barcelona. A database was created by combining data from the BCASA rain gauge network and XRAD radar products from April 2013 to December 2018. The methods used were also able to identify some areas in the city with a greater concentration of storm centroids than others. Results showed 207 significant rainfall episodes in the ROI for the six years, which were mainly concentrated between September and November. The fact that significant episodes were usually produced by highly convective rain corroborates the advantage of using radar images as a tool to detect any maxima even when no rain gauge is there. In 64 of the episodes, the level of pre-alert was achieved with a maximum frequency between August and September. The proposed 
algorithm showed more than 8000 centroids of convective cells from 189 cases. While maximum surface reflectivity over $45 \mathrm{dBZ}$ was more prone to occur near the coastline, the centroids of storm cells tended to concentrate more inland. Finally, from the 64 rainfall episodes that achieved the level of pre-alert or alert, a higher concentration of convective cells was found in the middle of the city with a time distribution that agrees with the maximum for convection activity (diurnal heating). The unexpectedly large number of centroids identified at night may be a consequence of unfiltered anomalous propagation.

Although this study focused on a small area, a more detailed analysis would provide a greater understanding of flash floods in Barcelona. A wider study period is needed and impacts on the city must be gathered more robustly. Furthermore, the usage of urban meteorological and hydrological models should be considered. For all these reasons, the role of specific institutions, such as BCASA, is increasingly important. Data need to be stored, cleaned, and analysed in robust ways, and monitoring and management systems need to be continually reviewed and improved in order to increase resilience to flash floods in Barcelona.

Author Contributions: Conceptualisation, L.E., M.C.L. and T.R.; methodology, L.E. and T.R.; software, L.E.; validation, L.E., T.R., B.A. and M.C.L.; writing—original draft preparation, L.E.; writingreview and editing, M.C.L. and T.R. All authors have read and agreed to the published version of the manuscript.

Funding: This research received no external funding.

Institutional Review Board Statement: Not applicable.

Informed Consent Statement: Not applicable.

Data Availability Statement: Not applicable.

Acknowledgments: This work was carried out under the framework of the SINOPTICA (H2020SESAR-2019-2, 892362) European project of Horizon 2020 and the M-CostAdapt (CTM2017-83655-C22-R) research project, funded by the Spanish Ministry of Economy and Competitiveness (MINECO/ AEI/FEDER, UE). The authors would like to thank BCASA for their commitment, collaboration, and data. Thanks also go to the Meteorological Service of Catalonia for their collaboration and the data provided. Finally, thanks go to the Water Research Institute (Instituto de Investigación del Agua-IdRA) and the SINOPTICA (H2020-SESAR-2019-2, 892362) European project of Horizon 2020 for enabling this paper to be written. Thank you to Hannah Bestow for her revision of the English.

Conflicts of Interest: The authors declare no conflict of interest.

\section{Appendix A}

Table A1. List of the 207 rainfall episodes inside ROI resulting from the combination of XRAD and BCASA data.

\begin{tabular}{|c|c|c|c|c|c|c|c|c|c|c|c|}
\hline Date & $\begin{array}{l}P_{\max } \\
\text { BCASA }\end{array}$ & $\begin{array}{l}P_{\text {max }} \\
\text { XRAD }\end{array}$ & Date & $\begin{array}{c}P_{\max } \\
\text { BCASA }\end{array}$ & $\begin{array}{l}P_{\max } \\
\text { XRAD }\end{array}$ & Date & $\begin{array}{c}P_{\max } \\
\text { BCASA }\end{array}$ & $\begin{array}{l}P_{\max } \\
\text { XRAD }\end{array}$ & Date & $\begin{array}{c}P_{\max } \\
\text { BCASA }\end{array}$ & $\begin{array}{l}P_{\max } \\
\text { XRAD }\end{array}$ \\
\hline 25 April 2013 & 17.4 & 16.2 & 17 September 2014 & 4.3 & 13.0 & 22 July 2016 & 18.6 & 21.9 & 26 January 2018 & 62.1 & 51.5 \\
\hline 27 April 2013 & 23.6 & 28 & 22 September 2014 & 9.7 & 20.1 & 30 August 2016 & 12.3 & 13.0 & 1 February 2018 & 16.2 & 10.0 \\
\hline 28 April 2013 & 13.4 & 14.4 & 23 September 2014 & 6.0 & 10.0 & 10 September 2016 & 11.5 & 5.0 & 4 February 2018 & 27.9 & 38.9 \\
\hline 29 April 2013 & 16.7 & 27.8 & 28 September 2014 & 95.4 & 101.2 & 13 September 2016 & 24.9 & 28.1 & 5 February 2018 & 39.2 & 39.9 \\
\hline 15 May 2013 & 32.7 & 38.3 & 29 September 2014 & 21.3 & 7.0 & 14 September 2016 & 18.2 & 20.8 & 8 February 2018 & 45.2 & 16.8 \\
\hline 16 May 2013 & 6.7 & 17.7 & 30 September 2014 & 46.3 & 35.3 & 23 September 2016 & 57.4 & 69.4 & 12 February 2018 & 20.6 & 19.0 \\
\hline 18 May 2013 & 7.9 & 10.8 & 5 October 2014 & 12.4 & 17.8 & 6 October 2016 & 31.5 & 28.1 & 28 February 2018 & 13.9 & 15.9 \\
\hline 19 May 2013 & 16.5 & 23.8 & 3 November 2014 & 44.6 & 45.5 & 12 October 2016 & 61.1 & 77.7 & 20 March 2018 & 45.4 & 35.4 \\
\hline 20 May 2013 & 10.3 & 12.1 & 4 November 2014 & 18.9 & 15.3 & 13 October 2016 & 62.2 & 54.0 & 24 March 2018 & 58.4 & 47.7 \\
\hline 8 June 2013 & 25.1 & 28.8 & 26 November 2014 & 35.4 & 35.3 & 22 October 2016 & 8.2 & 10.0 & 26 March 2018 & 13.5 & 16.0 \\
\hline 21 June 2013 & 5.6 & 15.5 & 27 November 2014 & 14.4 & 16.4 & 22 November 2016 & 12.6 & 13.4 & 8 April 2018 & 10.3 & 9.0 \\
\hline 18 July 2013 & 33.4 & 36 & 29 November 2014 & 52.1 & 40.3 & 23 November 2016 & 28.5 & 32.5 & 10 April 2018 & 10.0 & 8.0 \\
\hline 29 July 2013 & 3.8 & 12.1 & 30 November 2014 & 40.4 & 53.3 & 27 November 2016 & 14.0 & 21.9 & 11 April 2018 & 35.4 & 30.7 \\
\hline 26 August 2013 & 19.3 & 15.5 & 15 December 2014 & 18.6 & 18.0 & 16 December 2016 & 19.3 & 16.5 & 13 April 2018 & 6.3 & 10.7 \\
\hline 27 August 2013 & 2 & 19.4 & 19 January 2015 & 13.4 & 13.9 & 19 December 2016 & 16.9 & 17.9 & 14 April 2018 & 10.1 & 12.0 \\
\hline 28 August 2013 & 2.6 & 15.1 & 4 February 2015 & 19.3 & 20.1 & 22 January 2017 & 6.9 & 13.0 & 1 May 2018 & 82.0 & 62.4 \\
\hline 7 September 2013 & 24.4 & 23.2 & 5 February 2015 & 0.0 & 23.9 & 27 January 2017 & 23.6 & 23.1 & 13 May 2018 & 7.9 & 12.7 \\
\hline 10 September 2013 & 1.5 & 83.4 & 4 March 2015 & 13.1 & 12.2 & 8 February 2017 & 14.2 & 16.4 & 22 May 2018 & 0.7 & 17.1 \\
\hline
\end{tabular}


Table A1. Cont.

\begin{tabular}{|c|c|c|c|c|c|c|c|c|c|c|c|}
\hline Date & $\begin{array}{c}P_{\max } \\
\text { BCASA }\end{array}$ & $\begin{array}{l}P_{\text {max }} \\
\text { XRAD }\end{array}$ & Date & $\begin{array}{c}P_{\max } \\
\text { BCASA }\end{array}$ & $\begin{array}{l}P_{\max } \\
\text { XRAD }\end{array}$ & Date & $\begin{array}{c}P_{\max } \\
\text { BCASA }\end{array}$ & $\begin{array}{l}P_{\max } \\
\text { XRAD }\end{array}$ & Date & $\begin{array}{c}P_{\max } \\
\text { BCASA }\end{array}$ & $\begin{array}{l}P_{\max } \\
X R A D\end{array}$ \\
\hline 11 September 2013 & 18.2 & 10.2 & 14 March 2015 & 22.5 & 12.5 & 13 February 2017 & 19.1 & 15.8 & 29 May 2018 & 11.0 & 9.0 \\
\hline 4 October 2013 & 14.1 & 15.8 & 21 March 2015 & 36.3 & 21.6 & 24 February 2017 & 15.7 & 14.7 & 3 June 2018 & 21.0 & 29.2 \\
\hline 6 October 2013 & 10.4 & 24.7 & 26 March 2015 & 11.8 & 17.5 & 3 March 2017 & 16.2 & 13.0 & 6 June 2018 & 39.8 & 37.2 \\
\hline 7 October 2013 & 17.2 & 55.8 & 19 May 2015 & 43.4 & 55.6 & 4 March 2017 & 12.7 & 10.0 & 7 June 2018 & 18.3 & 30.9 \\
\hline 8 October 2013 & 0.6 & 13.1 & 20 May 2015 & 34.3 & 28.5 & 24 March 2017 & 107.4 & 101.2 & 28 June 2018 & 3.5 & 12.2 \\
\hline 9 October 2013 & 3.8 & 14.1 & 11 June 2015 & 11.9 & 13.7 & 25 March 2017 & 24.1 & 25.6 & 16 July 2018 & 50.5 & 44.4 \\
\hline 11 October 2013 & 13.4 & 11.2 & 15 June 2015 & 29.9 & 26.6 & 1 April 2017 & 15.4 & 13.1 & 22 July 2018 & 18.7 & 15.5 \\
\hline 16 November 2013 & 40.1 & 56.7 & 16 June 2015 & 3.4 & 10.9 & 5 April 2017 & 9.1 & 10.1 & 17 August 2018 & 64.9 & 65.8 \\
\hline 17 November 2013 & 43.4 & 62.9 & 31 July 2015 & 10.0 & 14.2 & 26 April 2017 & 12.9 & 10.6 & 25 August 2018 & 4.0 & 13.0 \\
\hline 18 November 2013 & 41.4 & 49.3 & 1 August 2015 & 23.4 & 14.0 & 27 April 2017 & 25.4 & 22.9 & 30 August 2018 & 11.7 & 12.5 \\
\hline 19 December 2013 & 10.1 & 11.5 & 13 August 2015 & 32.7 & 32.3 & 11 May 2017 & 21.9 & 16.8 & 31 August 2018 & 73.2 & 77.5 \\
\hline 19 January 2014 & 35.4 & 25.1 & 15 August 2015 & 17.0 & 17.5 & 4 June 2017 & 24.0 & 24.1 & 1 September 2018 & 14.2 & 15.7 \\
\hline 29 January 2014 & 28.8 & 26.7 & 18 August 2015 & 18.2 & 26.7 & 5 June 2017 & 10.3 & 12.2 & 6 September 2018 & 92.2 & 94.9 \\
\hline 9 February 2014 & 13.9 & 13.6 & 10 September 2015 & 35.2 & 37.5 & 30 June 2017 & 8.9 & 12.9 & 7 September 2018 & 39.6 & 76.3 \\
\hline 30 March 2014 & 13.2 & 14.3 & 23 September 2015 & 19.0 & 13.9 & 25 July 2017 & 25.3 & 46.7 & 12 September 2018 & 40.5 & 41.1 \\
\hline 31 March 2014 & 10.9 & 12.2 & 29 September 2015 & 17.4 & 20.7 & 8 August 2017 & 14.0 & 14.2 & 15 September 2018 & 1.1 & 40.2 \\
\hline 3 April 2014 & 55.9 & 57.8 & 30 September 2015 & 26.5 & 23.2 & 31 August 2017 & 19.6 & 18.5 & 18 September 2018 & 40.0 & 27.0 \\
\hline 22 April 2014 & 30.5 & 12.4 & 3 October 2015 & 38.0 & 80.1 & 6 September 2017 & 11.1 & 20.8 & 7 October 2018 & 21.2 & 26.3 \\
\hline 26 May 2014 & 26.0 & 33.0 & 7 October 2015 & 38.9 & 69.4 & 9 September 2017 & 21.3 & 30.7 & 9 October 2018 & 102.8 & 118.2 \\
\hline 28 May 2014 & 28.1 & 25.2 & 8 October 2015 & 5.6 & 17.9 & 12 September 2017 & 7.5 & 33.2 & 10 October 2018 & 21.9 & 21.7 \\
\hline 30 May 2014 & 17.7 & 19.4 & 13 October 2015 & 13.9 & 22.2 & 14 September 2017 & 14.7 & 14.2 & 13 October 2018 & 14.0 & 12.2 \\
\hline 15 June 2014 & 27.7 & 38.9 & 26 October 2015 & 9.0 & 17.0 & 15 September 2017 & 8.0 & 10.0 & 14 October 2018 & 44.5 & 49.8 \\
\hline 16 June 2014 & 7.0 & 14.4 & 27 October 2015 & 7.8 & 14.9 & 18 September 2017 & 6.1 & 13.6 & 19 October 2018 & 18.9 & 28.9 \\
\hline 17 June 2014 & 14.3 & 28.4 & 2 November 2015 & 60.6 & 52.8 & 22 September 2017 & 37.1 & 17.8 & 27 October 2018 & 29.9 & 31.2 \\
\hline 4 July 2014 & 17.0 & 17.8 & 3 November 2015 & 7.2 & 53.4 & 26 September 2017 & 9.4 & 19.0 & 28 October 2018 & 9.8 & 14.1 \\
\hline 7 July 2014 & 30.0 & 47.2 & 27 February 2016 & 30.4 & 26.4 & 1 October 2017 & 13.4 & 35.8 & 29 October 2018 & 0.0 & 12.6 \\
\hline 28 July 2014 & 30.5 & 39.4 & 16 March 2016 & 29.4 & 19.7 & 18 October 2017 & 29.4 & 27.8 & 31 October 2018 & 60.1 & 52.5 \\
\hline 29 July 2014 & 6.6 & 15.1 & 20 March 2016 & 23.8 & 18.4 & 19 October 2017 & 92.0 & 95.4 & 5 November 2018 & 9.9 & 11.9 \\
\hline 2 August 2014 & 11.9 & 16.9 & 1 April 2016 & 19.5 & 19.2 & 20 October 2017 & 6.1 & 14.2 & 9 November 2018 & 37.7 & 32.1 \\
\hline 15 August 2014 & 14.4 & 19.9 & 5 April 2016 & 21.5 & 21.3 & 04 November 2017 & 10.8 & 14.6 & 14 November 2018 & 2.6 & 11.0 \\
\hline 22 August 2014 & 54.3 & 55.3 & 21 April 2016 & 30.0 & 35.3 & 25 November 2017 & 9.0 & 16.3 & 15 November 2018 & 138.5 & 133.4 \\
\hline 5 September 2014 & 10.9 & 14.1 & 18 June 2016 & 28.8 & 23.9 & 2 December 2017 & 0.0 & 21.4 & 18 November 2018 & 18.7 & 12.1 \\
\hline 14 September 2014 & 18.8 & 27.3 & 13 July 2016 & 4.8 & 12.8 & 7 January 2018 & 13.9 & 19.5 & 20 November 2018 & 11.0 & 10.9 \\
\hline 16 September 2014 & 20.3 & 46.8 & 14 July 2016 & 0.9 & 24.0 & 13 January 2018 & 9.3 & 11.2 & & & \\
\hline
\end{tabular}

Table A2. Rainfall episodes in Barcelona with NAB levels greater than or equal to 3. Maximum cumulative values of precipitation from radar data and rain gauges data are also provided along with the NAB level achieved and the number of incidents reported to Barcelona City Council.

\begin{tabular}{|c|c|c|c|c|}
\hline Date & $\mathbf{P}_{\max \operatorname{Rad}}$ & $P_{\max }$ BCASA & NAB & Incidents \\
\hline 8 June 2013 & 28.8 & 25.1 & 4 & 15 \\
\hline 18 July 2013 & 36.0 & 33.4 & 4 & \\
\hline 7 September 2013 & 23.2 & 24.4 & 3 & \\
\hline 4 October 2013 & 15.8 & 14.1 & 3 & \\
\hline 17 November 2013 & 62.9 & 43.4 & 3 & \\
\hline 19 January 2014 & 25.1 & 35.4 & 4 & \\
\hline 29 January 2014 & 26.7 & 28.8 & 3 & \\
\hline 3 April 2014 & 57.8 & 55.9 & 4 & 29 \\
\hline 22 April 2014 & 12.4 & 30.5 & 3 & \\
\hline 26 May 2014 & 33.0 & 26.0 & 3 & 28 \\
\hline 28 May 2014 & 25.2 & 28.1 & 3 & \\
\hline 30 May 2014 & 19.4 & 17.7 & 3 & 8 \\
\hline 15 June 2014 & 38.9 & 27.7 & 3 & 6 \\
\hline 17 June 2014 & 28.4 & 14.3 & 3 & 2 \\
\hline 4 July 2014 & 17.8 & 17.0 & 3 & \\
\hline 7 July 2014 & 47.2 & 30.0 & 3 & \\
\hline 28 July 2014 & 39.4 & 30.5 & 4 & 20 \\
\hline 29 July 2014 & 15.1 & 6.6 & 3 & \\
\hline 2 August 2014 & 16.9 & 11.9 & 3 & \\
\hline 15 August 2014 & 19.9 & 14.4 & 3 & \\
\hline 22 August 2014 & 55.3 & 54.3 & 4 & 8 \\
\hline
\end{tabular}


Table A2. Cont.

\begin{tabular}{|c|c|c|c|c|}
\hline Date & $P_{\max \operatorname{Rad}}$ & $P_{\max B C A S A}$ & NAB & Incidents \\
\hline 14 September 2014 & 27.3 & 18.8 & 3 & \\
\hline 16 September 2014 & 46.8 & 20.3 & 3 & \\
\hline 28 September 2014 & 101.2 & 95.4 & 4 & 26 \\
\hline 30 September 2014 & 35.3 & 46.3 & 3 & \\
\hline 3 November 2014 & 45.5 & 44.6 & 4 & 34 \\
\hline 26 November 2014 & 35.3 & 35.4 & 3 & 7 \\
\hline 29 November 2014 & 40.3 & 52.1 & 3 & 5 \\
\hline 30 November 2014 & 53.3 & 40.4 & 3 & 1 \\
\hline 19 May 2015 & 55.6 & 43.4 & 3 & 1 \\
\hline 20 May 2015 & 28.5 & 34.3 & 3 & 4 \\
\hline 1 August 2015 & 14.0 & 23.4 & 3 & \\
\hline 13 August 2015 & 32.3 & 32.7 & 3 & 4 \\
\hline 15 August 2015 & 17.5 & 17.0 & 3 & \\
\hline 10 September 2015 & 37.5 & 35.2 & 3 & 6 \\
\hline 29 September 2015 & 20.7 & 17.4 & 3 & \\
\hline 30 September 2015 & 23.2 & 26.5 & 3 & \\
\hline 3 October 2015 & 80.1 & 38 & 3 & 1 \\
\hline 7 October 2015 & 69.4 & 38.9 & 3 & \\
\hline 2 November 2015 & 52.8 & 60.6 & 4 & 2 \\
\hline 20 March 2016 & 18.4 & 23.8 & 3 & \\
\hline 18 June 2016 & 23.9 & 28.8 & 3 & \\
\hline 13 September 2016 & 28.1 & 24.9 & 3 & \\
\hline 23 September 2016 & 69.4 & 57.4 & 3 & \\
\hline 6 October 2016 & 28.1 & 31.5 & 4 & 58 \\
\hline 13 October 2016 & 54.0 & 62.2 & 3 & \\
\hline 24 March 2017 & 101.2 & 107.4 & 4 & 11 \\
\hline 25 July 2017 & 46.7 & 25.3 & 3 & \\
\hline 31 August 2017 & 18.5 & 19.6 & 3 & \\
\hline 19 October 2017 & 95.4 & 92.0 & 4 & 64 \\
\hline 26 January 2018 & 51.5 & 62.1 & 3 & \\
\hline 1 May 2018 & 62.4 & 82.0 & 3 & \\
\hline 6 June 2018 & 37.2 & 39.8 & 3 & \\
\hline 16 July 2018 & 44.4 & 50.5 & 4 & 72 \\
\hline 17 August 2018 & 65.8 & 64.9 & 4 & 25 \\
\hline 31 August 2018 & 77.5 & 73.2 & 3 & \\
\hline 6 September 2018 & 94.9 & 92.2 & 4 & 72 \\
\hline 7 September 2018 & 76.3 & 39.6 & 3 & \\
\hline 12 September 2018 & 41.1 & 40.5 & 4 & 11 \\
\hline 18 September 2018 & 27.0 & 40.0 & 3 & \\
\hline 9 October 2018 & 118.2 & 102.8 & 4 & 79 \\
\hline 14 October 2018 & 49.8 & 44.5 & 3 & \\
\hline 9 November 2018 & 32.1 & 37.7 & 3 & \\
\hline 15 November 2018 & 133.4 & 138.5 & 4 & 94 \\
\hline
\end{tabular}

\section{References}

1. Marchi, L.; Borga, M.; Preciso, E.; Gaume, E. Characterisation of Selected Extreme Flash Floods in Europe and Implications for Flood Risk Management. J. Hydrol. 2010, 394, 118-133. [CrossRef]

2. Llasat, M.C.; Barriendos, M.; Barrera, A.; Rigo, T. Floods in Catalonia (NE Spain) since the 14th Century. Climatological and Meteorological Aspects from Historical Documentary Sources and Old Instrumental Records. J. Hydrol. 2005, 313, 408-418. [CrossRef]

3. Llasat, M.C.; Llasat-Botija, M.; Rodriguez, A.; Lindbergh, S. Flash Floods in Catalonia: A Recurrent Situation. Adv. Geosci. 2010, 26, 105-111. [CrossRef]

4. Barnolas, M.; Llasat, M.C. A Flood Geodatabase and Its Climatological Applications: The Case of Catalonia for the Last Century. In Natural Hazards and Earth System Science; European Geosciences Union: Munich, Germany, 2007; pp. 271-281. [CrossRef]

5. Cortès, M.; Llasat, M.C.; Gilabert, J.; Llasat-Botija, M.; Turco, M.; Marcos, R.; Martín Vide, J.P.; Falcón, L. Towards a Better Understanding of the Evolution of the Flood Risk in Mediterranean Urban Areas: The Case of Barcelona. Nat. Hazards 2018, 93, 39-60. [CrossRef] 
6. Gascón, E.; Laviola, S.; Merino, A.; Miglietta, M.M. Analysis of a Localized Flash-Flood Event over the Central Mediterranean. Atmos. Res. 2016, 182, 256-268. [CrossRef]

7. Llasat, M.C.; Marcos, R.; Turco, M.; Gilabert, J.; Llasat-Botija, M. Trends in Flash Flood Events versus Convective Precipitation in the Mediterranean Region: The Case of Catalonia. J. Hydrol. 2016, 541, 24-37. [CrossRef]

8. Barrera, A.; Llasat, M.C.; Barriendos, M. Estimation of Extreme Flash Flood Evolution in Barcelona County from 1351 to 2005. Nat. Hazards Earth Syst. Sci. 2006, 6, 505-518. [CrossRef]

9. Llasat, M.C.; Marcos, R.; Llasat-Botija, M.; Gilabert, J.; Turco, M.; Quintana-Seguí, P. Flash Flood Evolution in North-Western Mediterranean. Atmos. Res. 2014, 149, 230-243. [CrossRef]

10. Llasat, M.C.; López, L.; Barnolas, M. Flash-Floods in Catalonia: The Social Perception in a Context of Changing Vulnerability. Adv. Geosci. 2008, 17, 63-70. [CrossRef]

11. Blöschl, G.; Viglione, A.; Montanari, A. Emerging Approaches to Hydrological Risk Management in a Changing World. In Climate Vulnerability: Understanding and Addressing Threats to Essential Resources; Elsevier Inc.: Amsterdam, The Netherlands, 2013; pp. 3-10. [CrossRef]

12. Llasat, M.C.; Llasat-Botija, M.; López, L. A Press Database on Natural Risks and Its Application in the Study of Floods in Northeastern Spain. Nat. Hazards Earth Syst. Sci. 2009, 9, 2049-2061. [CrossRef]

13. Nakamura, I.; Llasat, M.C. Policy and Systems of Flood Risk Management: A Comparative Study between Japan and Spain. Nat. Hazards 2017, 87, 919-943. [CrossRef]

14. United Nations for Disaster Risk Reduction. Hazard. Definition E Classification Review; United Nations: New York, NY, USA, 2020.

15. IPCC. 2014: Climate Change 2014: Synthesis Report. Contribution of Working Groups I, II and III to the Fifth Assessment Report of the Intergovernmental Panel on Climate Change; Core Writing Team, Pachauri, R.K., Meyer, L.A., Eds.; IPCC: Geneva, Switzerland, 2014; 151p.

16. Drost, R.; Casteel, M.; Libarkin, J.; Thomas, S.; Meister, M. Severe Weather Warning Communication: Factors Impacting Audience Attention and Retention of Information during Tornado Warnings. Weather Clim. Soc. 2016, 8, 361-372. [CrossRef]

17. Cortès, M.; Turco, M.; Llasat-Botija, M.; Llasat, M.C. The Relationship between Precipitation and Insurance Data for Floods in a Mediterranean Region (Northeast Spain). Nat. Hazards Earth Syst. Sci. 2018, 18, 857-868. [CrossRef]

18. Naylor, J.; Sexton, A. The Relationship between Severe Weather Warnings, Storm Reports, and Storm Cell Frequency in and around Several Large Metropolitan Areas. Weather Forecast. 2018, 33, 1339-1358. [CrossRef]

19. Doswell, C., III; Ramis, C.; Romero, R.; Alonso, S. A Diagnostic Study of Three Heavy Precipitation Episodes in the Western Mediterranean Region. Weather Forecast. 1998, 13, 102-124. [CrossRef]

20. Rigo, T.; Llasat, M.C. A Methodology for the Classification of Convective Structures Using Meteorological Radar: Application to Heavy Rainfall Events on the Mediterranean Coast of the Iberian Peninsula. Nat. Hazards Earth Syst. Sci. 2004, 4, 59-68. [CrossRef]

21. Bech, J.; Vilaclara, E.; Pineda, N.; Rigo, T.; López, J.; O’hora, F.; Lorente, J.; Sempere, D.; Fàbregas, F.X. The Weather Radar Network of the Catalan Meteorological Service: Description and Applications. In Proceedings of the ERAD (2004), Visby, Sweden, 1 January 2004; pp. 416-420.

22. Cáceres, R.; Codina, B. Radar Data Assimilation Impact over Nowcasting a Mesoscale Convective System in Catalonia Using the WRF Model. Tethys 2018, 15, 3-17. [CrossRef]

23. Trapero, L.; Bech, J.; Rigo, T.; Pineda, N.; Forcadell, D. Uncertainty of Precipitation Estimates in Convective Events by the Meteorological Service of Catalonia Radar Network. Atmos. Res. 2009, 93, 408-418. [CrossRef]

24. Steiner, M.; Smith, J.A.; Burges, S.J.; Alonso, C.V.; Darden, R.W. Effect of Bias Adjustment and Rain Gauge Data Quality Control on Radar Rainfall Estimation. Water Resour. Res. 1999, 35, 2487-2503. [CrossRef]

25. Barcelona Cicle de l'Aigua, S.A.; CLABSA. Informe de Pluja [Versió Resumida]: Període del 21 de Setembre al 22 de Setembre de 1995. Available online: https://bcnroc.ajuntament.barcelona.cat/jspui/handle/11703/118351 (accessed on 1 March 2021).

26. Malgrat Bregolat, P.; Vilalta i Cambra, A.; Verdejo, J.M. Los Depositos de Retencion de Aguas Pluviales de Barcelona: Un Nuevo Enfoque en la Lucha Contra las Inundaciones y la Proteccion Medioambiental. Available online: https://www.osti.gov/etdeweb/ biblio/20567346 (accessed on 7 April 2021).

27. Berenguer, M.; Lee, G.; Sempere-Torres, D.; Zawadzki, I. A Variational Method for Attenuation Correction of Radar Signal. Proceedings of 2nd European Radar Conference, Delft, The Netherlands, 18-22 November 2002; European Meteorological Society: Delft, Holland, 2002; Volume 11.

28. Gjertsen, U.; Sálek, M.; Michelson, D.B. Gauge Adjustment of Radar-Based Precipitation Estimates in Europe. In Proceedings of the ERAD (2004), Visby, Sweden, 1 January 2004; pp. 7-11.

29. Rigo, T.; Llasat, M.C. Forecasting Hailfall Using Parameters for Convective Cells Identified by Radar. Atmos. Res. 2016, 169, 366-376. [CrossRef]

30. Wilson, J.W.; Feng, Y.; Chen, M.; Roberts, R.D. Nowcasting Challenges during the Beijing Olympics: Successes, Failures, and Implications for Future Nowcasting Systems. Weather Forecast. 2010, 25, 1691-1714. [CrossRef]

31. del Moral, A. Of Severe Thunderstorms: Radar-Based Nowcasting of Severe Thunderstorms: A Better Understanding of the Dynamical Influence of Complex Topography and the Sea. Ph.D. Thesis, University of Barcelona, Barcelona, Spain, 2020.

32. Peleg, N.; Morin, E. Convective Rain Cells: Radar-Derived Spatiotemporal Characteristics and Synoptic Patterns over the Eastern Mediterranean. J. Geophys. Res. Atmos. 2012, 117. [CrossRef] 
33. del Moral, A.; Rigo, T.; Llasat, M.C. A Radar-Based Centroid Tracking Algorithm for Severe Weather Surveillance: Identifying Split/Merge Processes in Convective Systems. Atmos. Res. 2018, 213, 110-120. [CrossRef]

34. Barnolas, M.; Rigo, T.; Llasat, M.C. Characteristics of 2-D Convective Structures in Catalonia (NE Spain): An Analysis Using Radar Data and GIS. Hydrol. Earth Syst. Sci 2010, 14, 129-139. [CrossRef]

35. Davini, P.; Bechini, R.; Cremonini, R.; Cassardo, C. Radar-Based Analysis of Convective Storms over Northwestern Italy. Atmosphere 2012, 3, 33-58. [CrossRef]

36. Llasat, M.C. An Objective Classification of Rainfall Events on the Basis of Their Convective Features: Application to Rainfall Intensity in the Northeast of Spain. Int. J. Climatol. 2001, 21, 1385-1400. [CrossRef]

37. Bech, J.; Codina, B.; Lorente, J. Forecasting Weather Radar Propagation Conditions. Meteorol. Atmos. Phys. 2007, 96, 229-243. [CrossRef]

38. Steiner, M.; Smith, J.A. Use of Three-Dimensional Reflectivity Structure for Automated Detection and Removal of Nonprecipitating Echoes in Radar Data. J. Atmos. Ocean. Technol. 2002, 19, 673-686. [CrossRef]

39. del Moral, A.; del Carmen Llasat, M.; Rigo, T. Connecting Flash Flood Events with Radar-Derived Convective Storm Characteristics on the Northwestern Mediterranean Coast: Knowing the Present for Better Future Scenarios Adaptation. Atmos. Res. 2020, 238. [CrossRef]

40. Czigány, S.; Pirkhoffer, E.; Geresdi, I. Environmental Impacts of Flash Floods in Hungary. In Flood Risk Management: Research and Practice; Taylor \& Francis Group: London, UK, 2008. [CrossRef]

41. Yin, J.; Yu, D.; Yin, Z.; Liu, M.; He, Q. Evaluating the Impact and Risk of Pluvial Flash Flood on Intra-Urban Road Network: A Case Study in the City Center of Shanghai, China. J. Hydrol. 2016, 537, 138-145. [CrossRef]

42. Nardi, F.; Annis, A.; Biscarini, C. On the Impact of Urbanization on Flood Hydrology of Small Ungauged Basins: The Case Study of the Tiber River Tributary Network within the City of Rome. J. Flood Risk Manag. 2018, 11, S594-S603. [CrossRef]

43. Díaz-Sanz, J.; Robert, S.; Keller, C. Parameters Influencing Run-off on Vegetated Urban Soils: A Case Study in Marseilles, France. Geoderma 2020, 376, 114455. [CrossRef] 